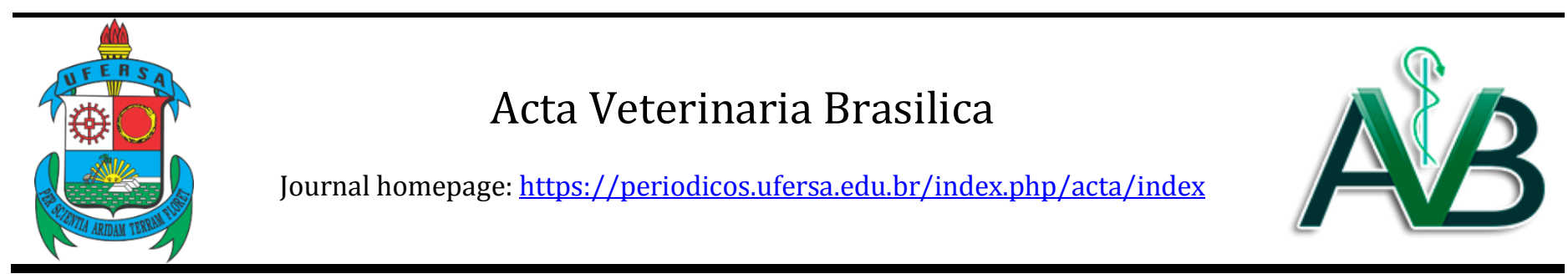

Clinical Report

\title{
Necrotizing Soft Tissue Infection in Dog - Case Report
}

\author{
Anaís Gabriela Villarreal Laguna1, Diefrey Ribeiro Campos²*, Monique Moraes Lambert², Daniel Paiva Barros de \\ Abreu$^{2}$, Miliane Moreira Soares de Souza3, Julio Israel Fernandes ${ }^{4}$ \\ 1 Aluna do Programa de Pós-Graduação em Medicina Veterinária (PPGMV), Universidade Federal Rural do Rio de Janeiro (UFRRJ). \\ 2. Aluno do Programa de Pós-Graduação em Ciências Veterinárias (PPGCV), Instituto de Veterinária (IV), Universidade Federal Rural do \\ Rio de Janeiro (UFRRJ) \\ 3 Departamento de Microbiologia e Imunologia Veterinária (DMIV), Instituto de Veterinária (IV), Universidade Federal Rural do Rio de \\ Janeiro (UFRRJ) \\ 4.Departamento de Medicina e Cirurgia Veterinária (DMCV), Instituto de Veterinária (IV), Universidade Federal Rural do Rio de Janeiro \\ (UFRRJ
}

\section{A R T I C L E I N F O}

\section{Article history}

Received 23 June 2017

Received in revised form 02 October 2017

Accepted 03 October 2017

\section{Keywords:}

Necrotizing fasciitis

Necrotizing cellulitis

Skin disease

\section{INTRODUCTION}

Necrotizing soft tissue infections (NSTI) are severe and can affect any stratum of the skin, subcutaneous tissue, superficial fascia and occasionally, it occurs in the deep fascia, muscle and adipose tissue. They are generally associated with disseminated necrosis, systemic toxicity and high mortality rates, if not treated early (MISHRA; SINGH; GUPTA, 2013; WEESE et al., 2009). These infections have a rapid course, and are mostly difficult to observe. Consequently, it is difficult to diagnose them before reaching an advanced stage (SHIROFF et al., 2014).

Generally, NSTIs are divided into two separated clinical entities: Type I and Type II, although clinical treatment is identical in both cases. Type I NSTI usually occur in patients who are elderly, sick and without any history of trauma. The affected areas are usually the abdomen and perineum; the infection is polymicrobial (SHIROFF et al., 2014), commonly involving Group A Streptoccocus and other aerobic (Streptococcos, Staphylococcos, Enterococcos) and anaerobic microorganisms (Bacteroides, Clostridium, Peptoestreptococos) (MISHRA; SINGH; GUPTA, 2013; WANG; LING, 2014). In Type II, NSTI patients are comparatively younger and healthier, with a history of cutaneous barrier damage, and the frequent occurrence of a trauma to an extremity. Infections are usually monomicrobial, frequently involving Group A $\beta$-hemolytic Streptococcus (Streptococcus pyogenes) and occasionally, Staphylococcus aureus (MISHRA; SINGH; GUPTA, 2013; SHIROFF et al., 2014). It has been associated with poor

\footnotetext{
* Corresponding author: diefrey8@hotmail.com
} 
health and immunocompromised individuals (SHIROFF et al., 2014).

Clinical signs like erythema, inflammation and sensitivity to palpation are all present in the early, and late stages of NSTI, and are undistinguishable in different presentations of the disease. Hemorrhagic bullas, crepitation, cutaneous insensitivity and necrosis of the skin tissue are considered late signs of the disease. Cutaneous sensitivity which exceeds the areas of visible changes in the skin is one of the most important physical signs for diagnosis. A combination of lack of sensitivity in the visibly affected area and acute systemic toxicity are highly suggestive of the presence of NSTI (SHIROFF et al., 2014; WANG; WONG; TAY, 2007; WANG; LING, 2014).

The most recommended diagnostic method is exploratory surgery. The diagnosis is considered positive when there is a greyish and necrotic tissue, purulent fluid, lack of resistance to digital pressure of the facial plains and when little to no bleeding of the areas is observed. NSTI are rare in dogs and their prevalence has not been completely clarified (MAYER; RUBIN, 2012; TORO; VILLARROEL, 2015; WEESE et al., 2009).

The treatment of these diseases entails surgical debridement, ample specter antibiotics, systemic support and constant monitoring (ANAYA; DELLINGER,
2007). The objective of this study was to describe a case of NSTI in a dog, and its successful clinical treatment.

\section{CASE DESCRIPTION}

A 6-year-old female Beagle, was found in the kennels in lateral decubitus, apathetic with pale mucous membranes. A wound in the dorso-lumbar, with scabbing and exudation was observed. A fight amongst the dogs in the kennel was suspected. While being carried to the infirmary, the animal presented intense pain in the lateral areas, and in the ventral abdomen.

Following a thorough physical exam, only a small perforated wound, about one centimeter in diameter, was found in the dorso-lumbar area. Although the external lesion was minuscule, the outer tissue surrounding it was inflamed, erythematous and crepitations could be felt during palpation of the area. A tissue section near the perforated lesion, of about four centimeters in diameter, had a blackish coloring and presented total loss of sensitivity. The area that presented edema, inflammation and crepitations extended through the left side of the animal, towards the right mammary glands, which were also inflamed. After a complete trichotomy of the area, a change in skin color and loss of sensitivity in various regions was observed.

Figure 1 - Trichotomy of the right side of the animal.

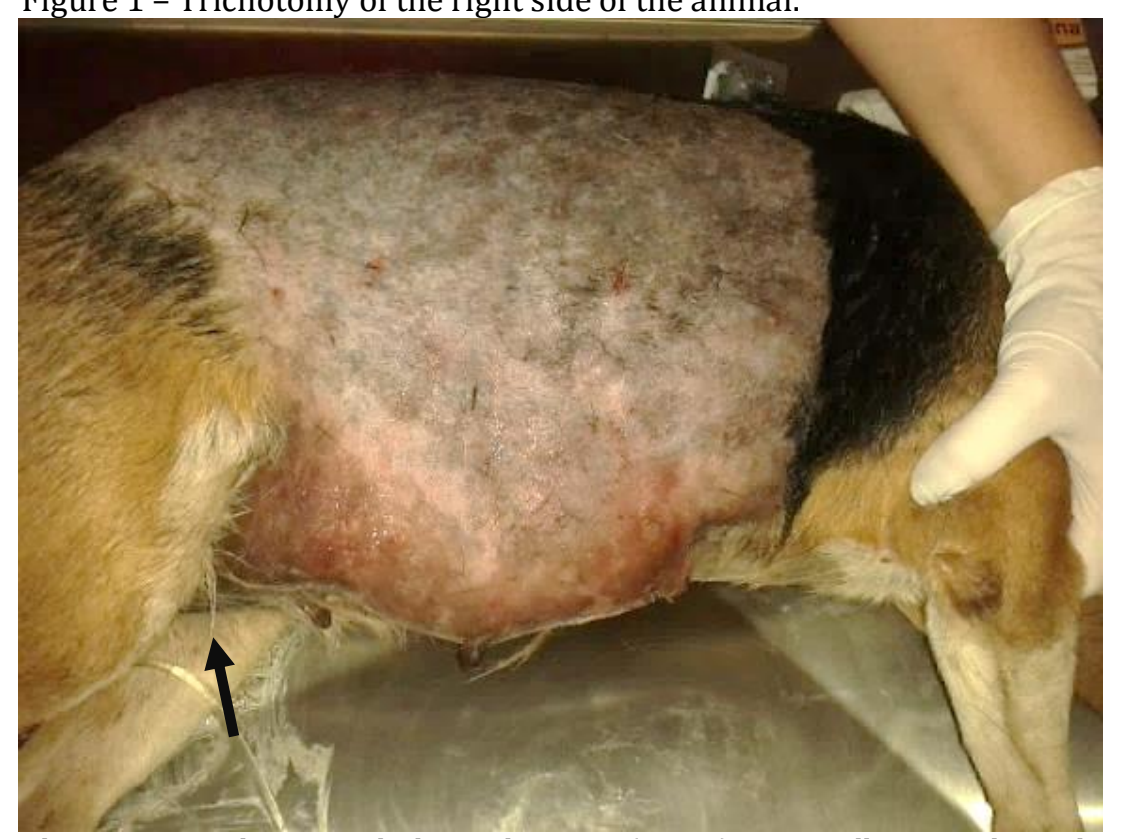

Alterations in the normal skin coloration (arrow), especially near the right mammary gland. Source: Author's personal archive.

A complete blood analysis was done, and the following results were obtained: normocytic, normochromic

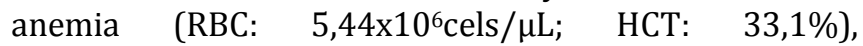
anisocytosis, neutrophilia and relative lymphopenia. The results for total proteins $(8,2 \mathrm{~g} / \mathrm{dL}[5,4-7,5 \mathrm{~g} / \mathrm{dL}])$, globulins (5,7 g/dL [2,4 - 4,4 g/dL]), ALPK (152 U/L [1,0
- 114,0 U/L]), AST (153 U/L [8,9 - 49,0 U/L]) and BUN $(42,0 \mathrm{mg} / \mathrm{dL}[15,0-40,0 \mathrm{mg} / \mathrm{dL}])$ were also altered.

A tissue sample was collected for histopathological evaluation, and aerobic microbial culture, by utilizing a $0,8 \mathrm{~cm}$ skin punch. Two fragments were collected from 
areas close to the puncture wound, and another tissue sample was collected from the skin near the right mammary glands (fig. 2A). When the fragments were extracted, a great amount of purulent and fetid material poured from the openings (fig. 2B). The places where the skin punch biopsy were obtained were left open to help with deep cleanings and drainage of the affected areas. It was also observed that in the lateral right side of the animal, it seemed that the skin did not adhere to the subcutaneous tissue.

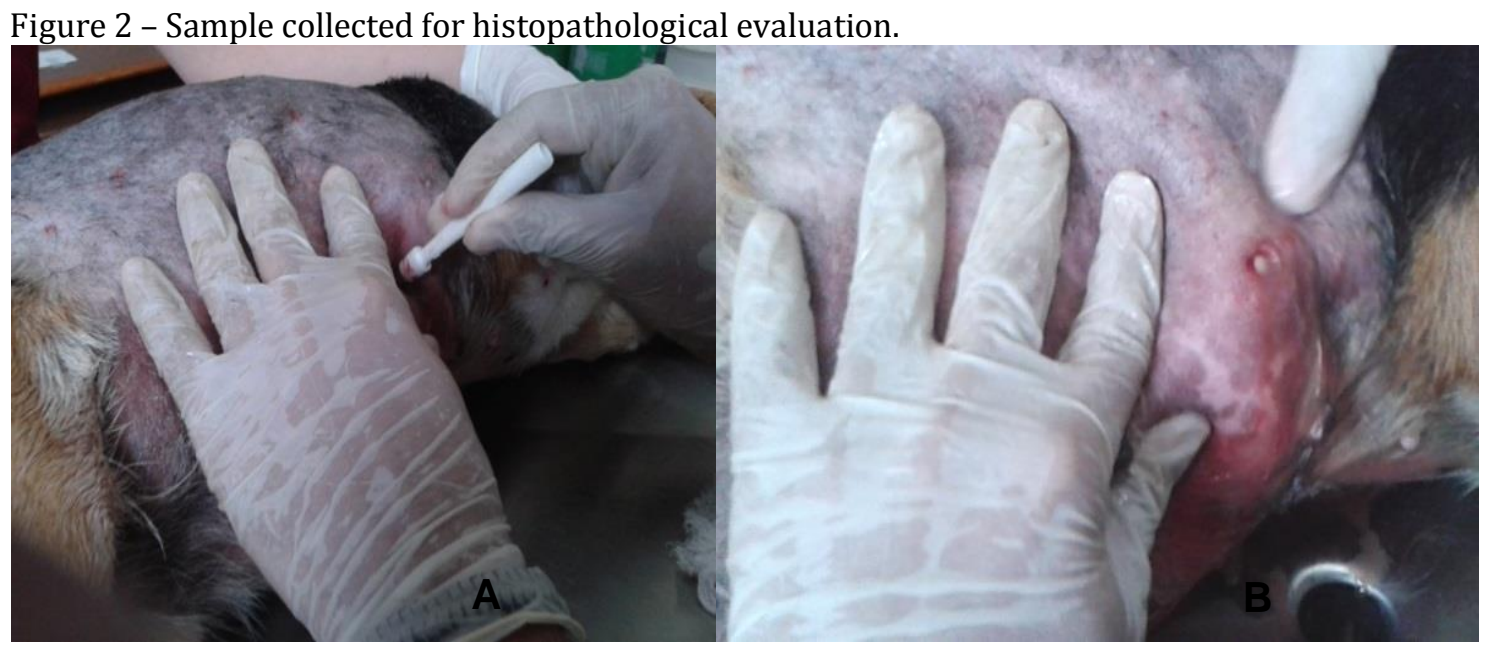

Collection of cutaneous fragments of $0,8 \mathrm{~cm}(\mathrm{~A})$; Presence of purulent exudate of area, immediately after tissue sample collection (B). Source: author's personal archive.

Microbiological isolations allowed us to obtain two different colonies, identified as Staphylococcus pseudintermedius and Group B Streptococcus agalactiae, by utilizing the methodology preconized by Winn et al. (2008). The analysis of microbiological susceptibilities was done with a disc diffusion assay, according to the criteria described for the species in the CLSI (Clinical and Laboratory Standards Institute )-VET (2013). The results obtained for $S$. pseudintermedius were: Sensitive Ceftriaxone, Enrofloxacin, Amoxicillin and Clavulanic Acid, Penicillin, Gentamicin, Sulfamethoxazole as well as Trimethoprim, and Azithromycin. The results for Streptococcus agalactiae (type B Streptococcus) were: Sensitive - Ceftriaxone and Amoxicillin and Clavulanic Acid. Samples for anaerobial culture were not collected.

Since the samples for anaerobial culture were not collected, treatment with Metronidazol was continued, even after obtaining the antibiogram results, because of the possibility that an anaerobial microorganism was also present.

The histological cuts revealed areas of predominant neutrophilic or fibrinous infiltration of the subcutaneous tissue, with no presence of neoplastic cells. The histopathological diagnosis was "necrotizing fibrinopurulent cellulitis".

The established treatment was a combination of Sodic Ceftriaxone (50 mg/kg IV 12/12h) and Metronidazole (25 mg/kg IV 12/12h), plus the analgesic Tramadol Clorhidrate (4 mg/kg IV 8/8h). Wound management included extensive cleanings every twelve hours, with a dilution of iodopovidone $(0,01 \%)$, applied with pressure. A silver sulfadiazine cream was applied to the external lesions, and was also used subcutaneously. Compressive bandages were used throughout the treatment.

Approximately fifteen days after starting the treatment, the biochemical test values were normalized, but the abnormalities in the blood panel persisted. The normochromic normocytic anemia was greater (RBC: 4,41×106 cels/ $\mu \mathrm{L}$; HCT: $28,8 \%$ ), and there was a higher reticulocyte count, with the presence of anisocytosis, polichromasia and erythrocyticrouleax.

After a month of treatment, the patient presented a considerable clinical improvement, although a mild normochromic normocytic anemia was still present (RBC 4,92x106 cells/ $\mu \mathrm{L} ;$ HGB10,8 d/dL; HCT 33,3\%). Skin recovery and growth were successful, with just a small area of scar tissue in the initial area of necrosis on the dorso-lumbar area, and in the local biopsy in the right mammary gland.

\section{DISCUSSION}

In the case described, the initial suspicion was that the perforated lesion of one centimeter in diameter was caused by a fight, since the animal was in a collective kennel. Trauma and penetrating wounds, like the one presented by the patient have been reported as causes for necrotizing infections (CABALLERO et al., 2012). Prescott et al. (1995) described how minor trauma can cause an abrupt and severe clinical condition, characterized by hypotension and necrotizing infection, which can evolve to sepsis.

At the moment of evaluation, one of the most noticeable clinical signs was the intense pain the animal presented 
during manipulation. One of the main characteristics of STNI is the intense pain which was disproportionate to the cutaneous lesion, or the clinical signs that were observed (CABALLERO et al., 2012; SHIROFF et al., 2014; WANG; LING, 2014).

Cutaneous signs like inflammation, edema, erythema and crepitations are also common to STNI, and were all observed in the patient. Even though these signs are common, it is important to mention that their absence does not exclude the existence of infection (CABALLERO et al., 2012; SHIROFF et al., 2014; WANG; WONG; TAY, 2007).

Hematological and biochemical alterations are commonly found in animals that carry this condition. These alterations occur because of a septic process, which is severe most of the time and leads to anemia and leukocytosis. Normally, leukocytosis is neutrophilic, and a deviation to the left may occur (MAYER; RUBIN, 2012; PALUMBO et al., 2011; TORO; VILLARROEL, 2015).

To be certain that the samples for bacterial culture are accurate, they must be taken from tissues in the periphery of necrotic areas (CABALLERO et al., 2012), as was performed in the patient. The isolates obtained were S. pseudintermedius and Group B S. agalactiae, both have been previously reported on the skin of dogs (LAMM et al., 2010). As a result of their potential to produce virulent enzymatic factors and toxins, they favor the development of necrotizing infections. These results, and the possibility of a perforated lesion due to a bite, can be diagnosed as a provable Type II NSTI, although it is a polymicrobial one. Necrotizing infections in a dog caused by $S$. pseudintermedius have already been reported by Weese et al. (2009). It has been reported that a high amount of NSTI are of a polymicrobial kind, and many of them include organisms of the Streptococcus species (ANAYA; DELLINGER, 2007; LAMM et al., 2010).

Even though surgery is the first choice of treatment described by many authors (ANAYA; DELLINGER, 2007; CABALLERO et al., 2012; MISHRA; SINGH; GUPTA, 2013; SHIROFF et al., 2014), if that was the therapy chosen for this case, the removal of large quantities of skin, subcutaneous tissue and muscle would have been necessary. This would have posed a risk to our patient's life.

Treatment with extensive cleanings every twelve hours, with a dilution of iodopovidone $(0,01 \%)$, applied with pressure was chosen because it helps the removal of cellular debris and reduces bacterial contamination. The silver sulfadiazine used after the deep cleanings, also possesses immediate bactericidal effects, and residual bacteriostatic effects (ATIYEH et al., 2009).

Early treatment with ample specter antibiotics, like ceftriaxone and metronidazole, was crucial to control the infection (WANG; LING, 2014). Treatment with metronidazole was continued, even though the aerobic culture came with a "resistant" result, since no material was collected for anaerobic culture. It was still suspected that there could be an anaerobic organism also involved in the infection.

An early diagnosis, associated with frequent cleaning and ample specter antibiotics allowed for the therapeutic success of this case, without surgical intervention.

\section{CONCLUSION}

It is of utmost importance that veterinary practitioners have STNI as part of their differential diagnosis, as this will help with an early diagnosis and treatment. Only a hasty diagnosis and an adequate treatment can limit the mortality associated with the disease.

\section{REFERENCES}

ANAYA, D. A.; DELlingER, E. P. Necrotizing sof-tissue infection diagnosis and management. Clinical Infectious Disease, v. 44, n. 2, p. 705-710, 2007

ATIYEH, B. S. et al. Wound cleansing, topical antiseptics and wound healing. International wound journal, v. 6, n. 6, p. 420-430, 2009.

CABALLERO, P. P. et al. Actualización en fasciitis necrotizante. Seminarios de la Fundación Española de Reumatología, v. 13, n. 2, p. 41-48, 2012.

Clinical and Laboratory Standards Institute (CLSI) (2013) Performance Standards for Antimicrobial Disk and Diluition Susceptibility Tests for Bacteria Isolated From Animals; Approved Standards - 4 Ed, VET01-A4.

LAMM, C.G. et al. Streptococcal Infection in Dogs: A Retrospective Study of 393 Cases. Veterinary Pathology, v. 47, n. 3, p. 387-395, 2010.

MAYER, M. N.; RUBIN, J. E. Necrotizing fasciitis caused by methicillinresistant Staphylococcus pseudintermedius at a previously irradiated site in a dog. The Canadian Veterinary Journal, v. 53, n. 11, p. 1207, 2012.

MISHRA, S.P.; SINGH, S.; GUPTA, S.K. Necrotizing soft tissue infections: Surgeon's prospective. International Journal of Inflammation, v.23, n. 2, p. 609-628, 2013.

PALUMBO, M. I. P. et al. Fasceíte necrotizante: relato de dois casos. Clínica Veterinária, n. 96, n.2, p. 64-70, 2011.

PRESCOTT, J. F. et al. Canine streptococcal toxic shock syndrome in Ontario: An emerging disease? Canadian Veterinary Journal, v. 39, n. 3, p. 486-487, 1995.

SHIROFF, A. M. et al. Necrotizing soft tissue infectious.Journal of Intensive Care Medicine, v. 29, n. 3, p. 138-144, 2014.

TORO, E. T.; VILLARROEL, M. D. C. Necrotizingfasciitis in a dog: a case reporta/Fasciitis necrotizante enun perro: reporte de caso/Fascí́te necrotizante em um cão: relato de caso. CES MedicinaVeterinaria y Zootecnia, v. 10, n. 1, p. 64, 2015.

WANG, J. M.; LING, H. K. Necrotizing fasciitis: eight-year experience and literature review. The Brazilian Journal of Infectious Disease, v. 18, n. 2, p. 137-143, 2014. 
WANG, Y. S.; WONG, C. H.; TAY, Y. K. Staging of necrotizing fasciitis based on the evolving cutaneous features. International Journal of Dermatology, v. 46, n. 2, p. 1036-1041, 2007.

WEESE, J. S.; et al. Staphylococcus pseudintermediusnecrotizing fasciitis in a dog. Canadian Veterinary Journal, v. 50, n. 2, p. 655-665, 2009.

WINN, W. J. R. et al. Koneman's Color Atlas and Diagnostic Microbiology. 6 ed. Philadelphia: Lippincott Williams \& Wilkins, 2008. 